„TURYZM" 1995, t. 5, z. 2

Iwan I. Pirożnik

\title{
PARKI NARODOWE W SYSTEMIE OBSZARÓW TURYSTYCZNYCH BIALORUSI
}

LES PARCS NATIONAUX DANS LE SYSTÈME DES TERRAINS TOURISTIQUES EN BIÉLORUSSIE

\author{
NATIONAL PARKS IN THE SYSTEM OF TOURIST AREAS OF \\ BIELORUSSIA
}

\begin{abstract}
Rozpatruje się zagadnienia funkcji i roli parków narodowych w stworzeniu ekologicznego systemu obszarów chronionych. Przeanalizowano stopień komplementarności funkcji ekologiczno-ochronnych rezerwatów i parków narodowych z formami użytkowania turystycznego. Stwierdzono pewne dysproporcje w poziomie popytu i ksztaltowaniu areału terenów o celowym przeznaczeniu turystycznym. Przedstawiono ogólne zalożenia struktury przestrzennego zagospodarowania projektowanych parków narodowych na Białorusi oraz kompleks systemowych powiązań pomiędzy użytkownikami terenów parków narodowych.
\end{abstract}

1. WSTĘP

W warunkach rozwoju postępu naukowo-technicznego, przejścia do społeczeństwa postindustrialnego i wzrastającej antropopresji na środowisko przyrodnicze coraz większą wartość mają obszary unikatowych krajobrazów, tereny naturalnej przyrody o dużych wartościach ekologiczno-środowiskowych. W celu podtrzymania warunków prawidłowego funkcjonowania przyrody, zachowania równowagi ekologicznej i bogatej puli genetycznej, zapewnienia warunków życia w zdrowym i różnorodnym środowisku oraz racjonalnego wykorzystania zasobów naturalnych, coraz aktywniej jest prowadzona polityka ochrony przyrody, tworzenia ekologicznie spójnego systemu obszarów chronionych w skali krajów i kontynentów. Najcenniejsze i atrakcyjne przyrodniczo obszary o zróżnicowanych rygorach ochronnych od czasów ich powstania cieszą się dużym zainte- 
resowaniem turystycznym szerokich warstw społecznych. Niektóre typy obszarów chronionych, zwłaszcza parki narodowe, powstały z idei połączenia motywów naukowo-ekologicznych (zachowanie osobliwych ekosystemów, form przyrody nieożywionej, rzadkich lub ginących gatunków flory i fauny) i rekreacyjno-turystycznych (wypoczynek w czystym i zdrowym środowisku, edukacja ekologiczna).

W warunkach pogłębiającego się uprzemysłowienia i rozwoju urbanizacji, dywersyfikacji zapotrzebowań społecznych, kształtowanie systemu obszarów chronionych często nie nadąża za postępem cywilizacyjno-technologicznym. W takich warunkach zdarza się, że na obszary chronione o określonych funkcjach ekologiczno-krajobrazowych, wkraczają (pod presją popytu, uwarunkowań gospodarczych) inne formy użytkowania, do których te obszary nie sa przygotowane lub nie odpowiada to pierwotnym celom i idei ich utworzenia. Podobne zjawisko, w warunkach zmian systemowych i reformowania gospodarki, występuje w szeregu krajów Europy Środkowej i Wschodniej, gdzie system obszarów chronionych kształtował się w nieco odmiennych warunkach, przybierając różnorodne formy, odbiegające od wzorców światowych. Szereg takich zjawisk możemy obserwować na Białorusi, gdzie system obszarów chronionych od kilku lat ulega pewnej stagnacji, a nawet degradacji, a próby jego unowocześnienia nierzadko sprowadzają się do nie przemyślanych reorganizacji sposobów zarządzania, zmiany reżymów ochrony, form użytkowania czy poszerzania działalności gospodarczej. Często odbywa się to pod hasłami rozwoju ekoturystyki, nawiązania do wzorców światowych, co wymaga bardziej szczegółowej analizy roli obszarów chronionych w systemie obsługi turystycznej.

\section{PARKI NARODOWE W SYSTEMIE OBSZARÓW CHRONIONYCH}

System obszarów chronionych Białorusi intensywnie kształtował się dopiero w ciągu ostatnich 30 lat, chociaż pierwsze rezerwaty przyrodnicze powstały jeszcze w latach 20. (Berezinski rezerwat (zapowiednik) dla ochrony bobra został utworzony w 1925 r.). W systemie administracyjno-nakazowego, odgórnego, zarządzania całą gospodarką, w warunkach permanentnego niedoboru środków, uwzględnienie wewnątrzregionalnej dyferencjacji środowiska geograficznego poszczególnych republik byłego ZSRR nie było celem pierwszorzędnym, a skala wartości i atrakcyjności obszarów podlegających ochronie była postawiona zbyt wysoko według kryteriów ogólnozwiązkowych. Trudno ją było przekroczyć obiektom o znaczeniu regionalnym. Warto jednak podkreślić, że w istniejących warunkach, na obszarach byłego ZSRR ukształtowała się sieć obiektów chronionych nie mających bezpośrednich odpowiedników w praktyce światowej rezerwatów (zapowiedników) państwowych, o bardzo wysokiej wartości ekologiczno-przyrodniczej. Bardzo znaczna powierzchnia wielu z nich, kompleksowy charakter ochrony całościowego systemu ekologiczno-przyrodniczego, szeroko 
zakrojone badania naukowe, ograniczony dostęp do ich terytorium - wszystko to pozwoliło na zachowanie ich wysokiego stanu naturalności, czego nie udało się utrzymać w wielu innych przypadkach przy połączeniu funkcji ekologiczno-ochronnych z rozwojem turystyki w parkach narodowych. Wszystkie te cechy bez wątpienia odnoszą się do rezerwatów państwowych Białorusi, co podnosi ich wartość ekologiczno-przyrodniczą w skali Europy i świata.

Sieć obszarów chronionych Białorusi na początku lat 90. reprezentowały 3 państwowe rezerwaty, 1 park narodowy, 70 rezerwatów częściowych (zakazników), około 140 pomników przyrody i ponad 20 parków-pomników o krajowym znaczeniu, które zajmowały około $0,9 \mathrm{mln}$ ha powierzchni kraju (L u c z k ov 1993, P i r o żn i k 1993). Udział obszarów kompleksowej ochrony przyrody (rezerwaty, parki narodowe) wynosi $1,1 \%$ powierzchni kraju (tab. I), a obszarów chronionych wszystkich typów $-3,7 \%$. Jest to dwukrotnie mniej, niż zakładano w szeregu programów kształtowania ekologicznego systemu obszarów chronionych Białorusi, które przewidywały, że w 1995 r. powierzchnia obszarów chronionych osiągnie 2094 tys. ha, udział zapowiedników i parków narodowych wyniesie $2,4 \%$ powierzchni kraju, a wszystkich obszarów chronionych $-7,4 \%$ (M u r a u j e v 1994).

Tabela I

Rezerwaty państwowe i parki narodowe Bialorusi (1994 r.)

Les réserves d'état et les Parcs Nationaux de la Biélorussie (1944)

\begin{tabular}{|c|c|c|c|c|}
\hline \multirow{2}{*}{$\begin{array}{c}\text { Rezerwaty } \\
\text { i parki narodowe }\end{array}$} & \multirow{2}{*}{$\begin{array}{c}\text { Rok } \\
\text { powołania }\end{array}$} & \multirow{2}{*}{$\begin{array}{c}\text { Powierzchnia } \\
\text { w tys. ha }\end{array}$} & \multicolumn{2}{|c|}{ Liczba chronionych gatunków } \\
\hline & & & ssaków & ptaków \\
\hline $\begin{array}{l}\text { Bereziński rezerwat } \\
\text { biosfery }\end{array}$ & 1925 & 76,2 & 59 & 240 \\
\hline $\begin{array}{l}\text { Prypecki rezerwat kraj- } \\
\text { obrazowo-hydrologiczny }\end{array}$ & 1969 & 61,9 & 47 & 256 \\
\hline $\begin{array}{l}\text { Park narodowy } \\
\text { (rezerwat biosfery) } \\
\text { „Puszcza Białowieska” }\end{array}$ & 1957 & 98,6 & 59 & 227 \\
\hline $\begin{array}{l}\text { Poleski rezerwat } \\
\text { radiacyjno-ekologiczny }\end{array}$ & 1988 & $142,8^{*}$ & $\mathrm{x}$ & $\mathrm{x}$ \\
\hline
\end{tabular}

* Utworzony na obszarach radioaktywnego zanieczyszczenia po awarii elektrowni atamowej w Czarnobylu i nie uwzględniany przy obliczeniu udziału obszarów kompleksowej ochrony.

Zaburzenie równowagi ekologicznej na terytorium Białorusi, wywołane skutkami szeroko zakrojonej melioracji $(2,7 \mathrm{mln}$ ha poddane osuszeniu) i chemizacji w rolnictwie, nieracjonalnej eksploatacji surowców naturalnych, zanieczyszczenie wód, powietrza i gleb w miastach i okręgach przemysłowych oraz za- 
nieczyszczenia radioaktywnego, po katastrofie w Czarnobylu (46,5 tys. km² $23 \%$ terytorium kraju), wymaga intensyfikacji prac w celu kształtowania kompleksowego systemu obszarów chronionych. Przy takim założeniu powinny być uwzględnione jeszcze dwie okoliczności. Po pierwsze, zachowanie na terytorium Białorusi znacznych kompleksów leśnych - puszcz (Puszcza Białowieska 90 tys. ha, Nalibokska - 140 tys. ha, Grodzieńska - 40 tys. ha, Rużańska, Kotrańska, Szereszewska, Lipiczańska, Nieświeżska i in. - każda o powierzchni

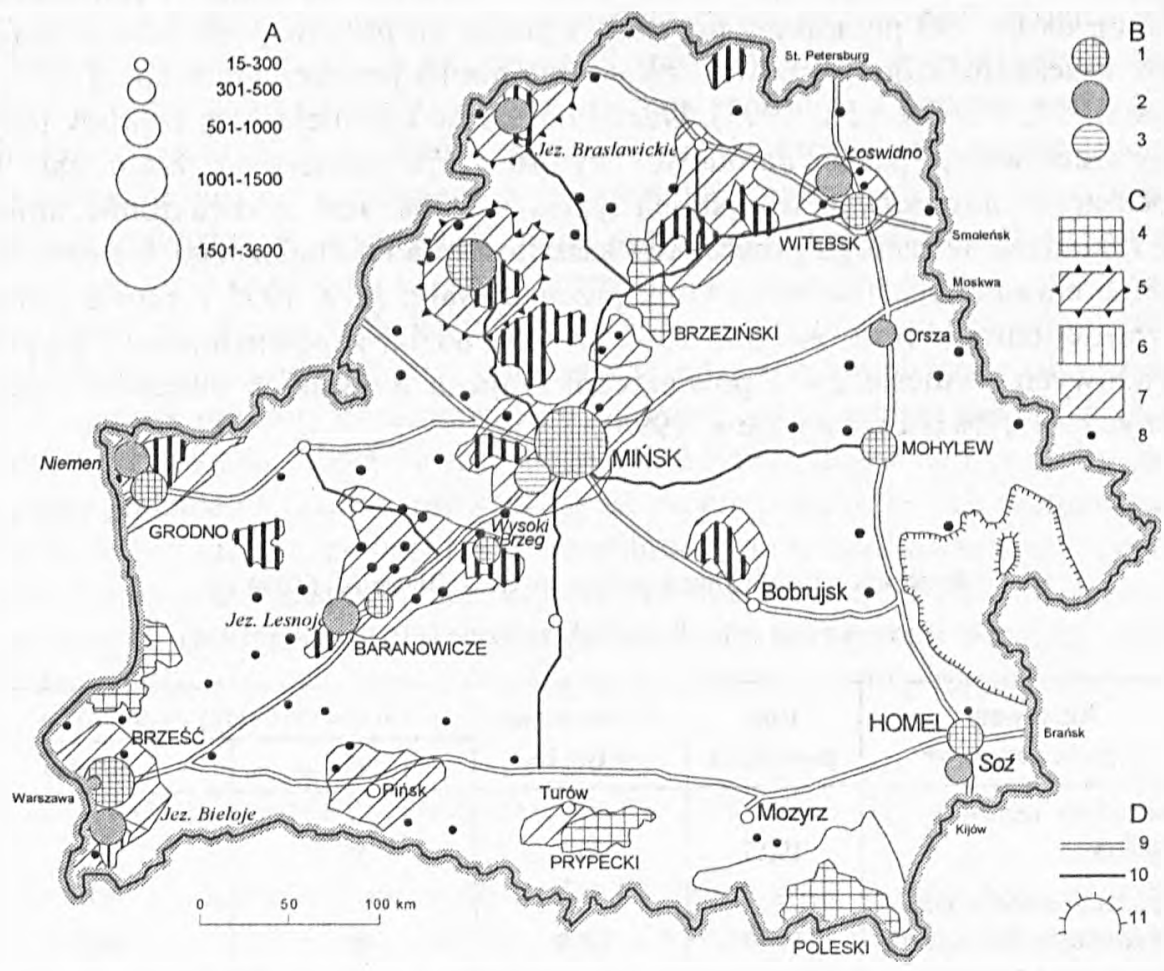

Rys. 1. Parki narodowe w systemie zagospodarowania turystycznego Bialorusi: A - liczba miejsc noclegowych w obiektach turystycznych; B - typy obiektów turystycznych: 1 - hotele, 2 - bazy turystyczne, 3 - motele i kempingi; C - obszary chronionego krajobrazu i turystyczne: 4 rezerwaty, 5 - projektowane parki narodowe, 6 - obszary turystyczne o znaczeniu krajowym, 7 strefy aktywizacji turystycznej, 8 - atrakcyjne miejscowości turystyczne o funkcjach krajoznawczych, D - drogi i granice: 9-główne drogi tranzytowe, 10-drogi tranzytowe, 11 -strefy zagrożenia ekologicznego

Dessin 1. Les parcs nationaux dans le système de l'aménagement touristique de la Biélorussie: A - nombre des lieux de couchage dans les objets touristiques; B - types des objets touristiques: 1 - hôtels, 2 - bases touristiques, 3 - motels et campings; $\mathrm{C}$ - terrains du paysage protégé: 4 - réserves, 5 -parcs nationaux projetés, 6 - terrains touristiques à l'importance nationale, 7 -zones de l'activité touristique, 8 - attrayantes localités touristiques aux fonctions chorographiques; D - routes et limites: 9 -routes principales de transit, 10-routes de transit, 11 -limites de la zone de menace écologique 
ponad 10 tys. ha), występujących w takiej skali w nielicznych krajach Europy, stwarza warunki do kształtowania - razem z przyległymi obszarami leśnymi Polski, Litwy, Rosji, Ukrainy - zielonych płuc całej Europy, których szczególne znaczenie powinno być uwzględnione w systemie obszarów chronionych Białorusi. Po drugie, stosowanie kryterium reprezentatywności wszystkich stref przyrodniczo-krajobrazowych w systemie obszarów chronionych wymaga powołania ich kompleksowych form (rezerwaty) w szeregu prowincji fizyczno-geograficznych, gdzie dotychczas takich obiektów nie ma. W celu zmiany takiej sytuacji było zakładane utworzenie zapowiedników państwowych $\mathrm{w}$ prowincji Zachodnio-Białoruskiej (Nalibokski - 64,3 tys. ha), Przedpoleskiej (Swisłocko-Berezyński - 20,0 tys. ha) oraz na Pojezierzu Białoruskim (Surażski). Jednak plany te nie zostały zrealizowane (brak środków finansowych w warunkach recesji, nie uzgodnienie interesów resortowych, opór władz lokalnych etc.; $\mathrm{Dz}$ j a t I a v 1994, M u r a u j e v 1994). Ustawa o ochronie środowiska naturalnego Białorusi z dnia 26 listopada 1992 r. ustanowiła cztery kategorie obszarów chronionych - rezerwaty, parki narodowe, rezerwaty częściowe i pomniki przyrody, tzn. wprowadziła nowy typ dotychczas nie występujący na Białorusi - parki narodowe. Jak zaznaczono, w praktyce sprowadziło się to do reorganizacji (w roku 1991) rezerwatowo-myśliwskiego gospodarstwa "Białowieżskaja Puszcza" w park narodowy (później uzyskał również status rezerwatu biosfery) oraz opracowaniu ogólnej koncepcji utworzenia parków narodowych na Pojezierzu (Naroczański, Brasławski), w pasie Wysoczyzny Białoruskiej („Belaja Ruś” - na Lagojszczynie) i Polesiu (Turowski) - rys. 1. Jednak brak realizacji tych założeń, wzrost presji zarówno wewnętrznego, jak i zagranicznego ruchu turystycznego na unikatowe obszary przyrodnicze, doprowadził do coraz liczniejszych prób rozszerzenia wykorzystania turystycznego obszarów chronionych, w tym w pierwszej kolejności zapowiedników i parków narodowych przy braku odpowiedniej infrastruktury i uzasadnionych planów zagospodarowania ich stref rekreacyjno-turystycznych.

\section{PARKI NARODOWE W SYSTEMIE OBSŁUGI TURYSTYCZNEJ}

Wzrost presji turystycznej na obszary chronionego krajobrazu przyrodniczego - w tym rezerwaty i parki narodowe - jest wywołany kilkoma czynnikami. Po pierwsze, struktura popytu turystycznego społeczeństwa zurbanizowanego (udział ludności miejskiej na Białorusi wynosi około 67\%), cechuje się wysokim popytem na aktywne formy turystyki pobytowej i wędrówkowej (ponad $60 \%$ popytu potencjalnego), ze szczególnym wskazaniem na obszary o wysokich walorach przyrodniczo-krajobrazowych (P i r o ż n i k 1992). Po drugie, dezintegracja polityczno-gospodarcza republik byłego ZSRR wywołała zaburzenia na rynku usług turystycznych i doprowadziła do jego kurczenia się na Białorusi do terytorium swojego kraju, którego stopień zagospodarowania nie odpowiada 
wzmożonemu popytowi i powoduje ekstensywne rozproszenie się ruchu turystycznego (w tym na atrakcyjne obszary krajobrazów naturalnych lub chronionych). Po trzecie, w warunkach pogorszenia się sytuacji materialnej w okresie przejściowych reform gospodarczych, wzrasta zainteresowanie przyrodniczo-zbierackimi formami turystyki i rekreacji, co często wywołuje kolizje z funkcjami ekologicznymi obszarów chronionych. $Z$ drugiej strony, liberalizacja reżymu wizowego i wysoka atrakcyjność obszarów chronionych dla zagranicznej turystyki myśliwskiej, spowodowała znaczny ruch turystów zagranicznych w zapowiednikach i parku narodowym na Białorusi. Wyłączenie znacznych obszarów kraju (ponad 1/5) z aktywnej penetracji turystycznej w wyniku zanieczyszczenia radioaktywnego regionów południowo-wschodnich, powoduje wzrost koncentracji i przesunięcie aktywnego wykorzystania turystycznego obszarów przyrodniczych ku środkowym, zachodnim i północno-zachodnim obszarom kraju.

W takiej sytuacji potwierdza się teza, że turystyka jest równorzędną w stosunku do innych formą użytkowania ziemi i wymaga dla swojego rozwoju odrębnego areału obszarów turystyczno-rekreacyjnych (P i ro żn i k 1976). Próba jej traktowania jako drugorzędnego użytkownika na obszarach o innych funkcjach (lasy państwowe, pasy zielone miast, tereny gospodarki wodnej i in.) nie rozwiązuje problemu przy znacznym natężeniu ruchu, a jest czynnikiem powstawania wielu konfliktów przestrzennych. W takiej sytuacji - braku wystarczającego funduszu terenów turystycznych - „łatwym” rozwiązaniem wydaje się być wprowadzenie funkcji turystycznej na obszary krajobrazu chronionego o wysokich walorach krajobrazowych i myśliwsko-zbierackich. W warunkach obniżenia środków finansowych wydatkowanych z budżetu państwa na utrzymanie rezerwatów i parku narodowego, zostają one zmuszone do poszukiwania dodatkowych źródeł finansowania i sięgają po rozszerzenie turystycznych form użytkowania ich terenów.

Jednak analiza stopnia komplementarności i możliwości turystycznego użytkowania obszarów chronionych wykazuje (tab. II), że w rezerwatach biosfery i rezerwatach jest możliwe uprawianie tylko form turystyki poznawczo-edukacyjnej (zwiedzanie muzeów przyrody, zwierzyńca, ścieżki ekologicznej, obserwacji ekologicznych lub imprez folklorystycznych, nawiązujących do miejscowych tradycji kultury ludowej). Wbrew opiniom panującym w niektórych środowiskach naukowców i praktyków organizacji ekologicznych oraz turystycznych, masowe formy turystyki nie mogą być zaakceptowane również w parkach narodowych, gdzie mogą być preferowane niektóre rodzaje wypoczynku pobytowego i wędrówkowego przy podstawowym znaczeniu tylko turystyki poznawczo-edukacyjnej lub zbieractwa (w strefach mniej ścisłej ochrony). Jedynie parki krajobrazowe (landszaftnyje, rekreacyjno-przyrodnicze), jako odrębny typ obszarów chronionych o połączonych funkcjach ekologiczno-ochronnych i turystycznych moga (przy odpowiednim poziomie zagospodarowania) stać się ob- 
szarami turystyki masowej. Przy tak określonych granicach komplementarności użytkowania turystycznego parków narodowych trzeba uznać, że nie rozwiązuja one problemu ksztaltowania funduszu terenów turystycznych, a raczej są jego elementami uzupełniającymi.

T a b e la II

Stopień komplementarności turystyki i rekreacji z funkcjami ekologicznymi na obszarach chronionych

La degré de l'harmonisation du tourisme et de la récréation avec les fonctions écologiques sur les terrains protégés

\begin{tabular}{|c|c|c|c|c|}
\hline \multirow[b]{2}{*}{$\begin{array}{c}\text { Formy turystyki } \\
\text { i rekreacji }\end{array}$} & \multirow[b]{2}{*}{ Rodzaje zajęć } & \multicolumn{3}{|c|}{ Typy obszarów chronionych } \\
\hline & & $\begin{array}{l}\text { rezerwaty, } \\
\text { rezerwaty } \\
\text { biosfery }\end{array}$ & $\begin{array}{c}\text { parki } \\
\text { narodowe }\end{array}$ & $\begin{array}{l}\text { parki kraj- } \\
\text { obrazowe }\end{array}$ \\
\hline $\begin{array}{l}\text { Uzdrowiskowo- } \\
\text {-kuracyjne }\end{array}$ & $\begin{array}{l}\text { Kuracja sanatoryjna } \\
\text { Ścieżki kuracyjne }\end{array}$ & $\varnothing$ & $\varnothing$ & $\otimes$ \\
\hline $\begin{array}{l}\text { Wypoczynkowo- } \\
\text {-pobytowe }\end{array}$ & $\begin{array}{l}\text { Rekreacja stacjonarna } \\
\text { Kapiele i plażowanie } \\
\text { Jazda na rowerze } \\
\text { Jazda konna } \\
\text { Biwakowanie } \\
\end{array}$ & $\begin{array}{l}\varnothing \\
\varnothing \\
\otimes \\
\varnothing \\
\varnothing\end{array}$ & $\begin{array}{l}\varnothing \\
\otimes \\
\oplus \\
\otimes \\
\varnothing\end{array}$ & $\begin{array}{l}\otimes \\
\oplus \\
\oplus \\
\oplus \\
\otimes\end{array}$ \\
\hline $\begin{array}{l}\text { Sportowo- } \\
\text {-wędrówkowe }\end{array}$ & $\begin{array}{l}\text { Turystyka piesza } \\
\text { Turystyka rowerowa } \\
\text { Zeglarstwo, kajakarstwo } \\
\text { Narty wodne, nurkowanie } \\
\text { Lodzie motorowe, mototurystyka } \\
\text { Gry sportowe, zabawy narodowe }\end{array}$ & $\begin{array}{l}\varnothing \\
\varnothing \\
\varnothing \\
\varnothing \\
\varnothing \\
\varnothing\end{array}$ & $\begin{array}{l}\otimes \\
\otimes \\
\varnothing \\
\varnothing \\
\varnothing\end{array}$ & $\begin{array}{l}\oplus \\
\oplus \\
\oplus \\
\varnothing \\
\varnothing \\
\oplus\end{array}$ \\
\hline $\begin{array}{l}\text { Poznawczo- } \\
\text {-edukacyjne }\end{array}$ & $\begin{array}{l}\text { Wycieczki ekologiczne } \\
\text { Ścieżki ekologiczne } \\
\text { Obserwacje naukowo-dydaktyczne } \\
\text { Szkolenie ekologiczne } \\
\text { Imprezy folklorystyczne }\end{array}$ & $\begin{array}{l}\oplus \\
\oplus \\
\oplus \\
\oplus\end{array}$ & $\begin{array}{l}\oplus \\
\oplus \\
\oplus \\
\oplus\end{array}$ & $\begin{array}{l}\oplus \\
\oplus \\
\oplus \\
\oplus\end{array}$ \\
\hline $\begin{array}{l}\text { Zbieracko- } \\
\text {-łowieckie }\end{array}$ & $\begin{array}{l}\text { Zbieranie grzybów, jagód, zioł } \\
\text { Wędkarstwo, myślistwo } \\
\text { Bartnictwo }\end{array}$ & $\begin{array}{l}\varnothing \\
\varnothing \\
\varnothing\end{array}$ & $\begin{array}{l}\otimes \\
\otimes\end{array}$ & $\begin{array}{l}\oplus \\
\oplus \\
\oplus\end{array}$ \\
\hline
\end{tabular}

$\varnothing$ - zakazane,

$\otimes-$ możliwe,

$\oplus$ - wskazane

Ź r ó d ło: opracowanie własne.

Nawiązując do koncepcji rozszerzenia typów obszarów chronionych, łączących funkcje ekologiczne-przyrodnicze i turystyczne, planuje się utworzenie na Białorusi, w atrakcyjnych regionach posiadających odpowiednie walory, parków narodowych (nacjonalnych). 
Park narodowy „Puszcza Białowieska” po stronie białoruskiej zajmuje około 90 tys. ha, gdzie na strefę ścisłej ochrony przypada około 10 tys. ha (11\% ogólnej powierzchni). Jest to unikatowy pod względem drzewostanów obszar lasów puszczańskich ze znaczną liczbą rzadkich gatunków fauny i flory (tab. I). Jego położenie peryferyjne w stosunku do największych aglomeracji miejskich nie sprzyja, w obecnej sytuacji gospodarczej, napływowi krajowego ruchu turystycznego, np. w $1993 \mathrm{r}$. liczba zwiedzających muzeum przyrody i zwierzyniec nie przekroczyła 9,5 tys. osób. W centrum administracyjnym parku (osiedle Kamieniuki) trwa rekonstrukcja hotelu na 150 miejsc, opracowano rowerowe trasy turystyczne. Pozostając na uboczu głównej trasy tranzytowej kraju (BrześćMińsk-Moskwa), trzeba liczyć na dalsze pełnienie przez PN „Puszcza Białowieska" funkcji edukacyjno-wycieczkowej oraz zagranicznej turystyki myśliwskiej (liczba niektórych gatunków zwierzyny kopytnej przekracza możliwości pokarmowe parku).

Berezyński rezerwat biosfery dysponuje bogatym muzeum przyrody, ścieżka ekologiczną w strefie buforowej oraz urządzoną trasą turystyki obserwacyjno-naukowej. Warto zwrócić uwagę, że strefa ścisłej ochrony zajmuje w nim około 22 tys. ha, co stanowi ponad $28 \%$ powierzchni rezerwatu. Jego dogodne położenie (140 km na północny wschód od aglomeracji stołecznej na trasie Minsk-Lepel-Witebsk) może stać się czynnikiem sprzyjającym intensyfikacji ruchu turystycznego, w tym - międzynarodowego.

Prypecki rezerwat krajobrazowo-hydrologiczny jest położony blisko obszarów zanieczyszczenia radioaktywnego, jednak ma wysokie walory myśliwskie. Funkcjonują w nim trasy turystyczne: samochodowa, piesza i wodna. Jego znaczenie jako obiektu turystycznego wzrośnie po uruchomieniu muzeum przyrodniczego w Turowie (z ekspozycją bartnictwa). Na przylegających obszarach jest rozważana idea utworzenia parku narodowego „Turowszczyna” (rys. 1).

\section{STRUKTURA ZAGOSPODAROWANIA PRZESTRZENNEGO PROJEKTOWANYCH PARKÓW NARODOWYCH}

Najbardziej zaawansowane są prace dotyczące utworzenia dwóch parków narodowych w strefie pojezierzy - Naroczańskiego i Brasławskiego.

Naroczański Park Narodowy planuje się na obszarze 69,7 tys. ha (według wariantu minimalnego). W jego granicach znajdą się: najbardziej zagospodarowana turystycznie grupa jezior naroczańskich, rezerwaty - krajobrazowy „Jeziora Błękitne” i hydrologiczny „Czeremczyca”, jeziora Małe i Wielkie Szwakszty ze znacznymi zasobami sapropelu leczniczego. Granice ustalane według kryterium ciągłości i spójności ekologicznej obejmują obszar o powierzchni 127,8 tys. ha, włączając w to rezerwat „Djagili”, jezior Świr' i Wisznewskoje. Maksymalny wariant zakłada włączenie w obręb parku jezior saroczańskich, krajobrazów doliny Wilii, co zwiększa jego powierzchnie do 184,4 tys. ha (rys. 2) (P o - 
t a e v, J u r g e n s o n, B u g a j e n k o 1993). Warto zwrócić uwagę, że przy minimalnej powierzchni parku (69,7 tys. ha) na strefę ścisłej ochrony przypada $13 \%$, regulowanej ochrony (zakazniki) - około $15 \%$, turystycznego zagospodarowania - $32 \%$ oraz strefę gospodarczą (przeważnie rolnicza) - $40 \%$ powierzchni parku. Tak więc udział strefy ścisłej ochrony jest porównywalny do Parku Narodowego „Puszcza Białowieska”, jednak obszary te nie tworzą jednolitej ciagłej przestrzennie strefy.

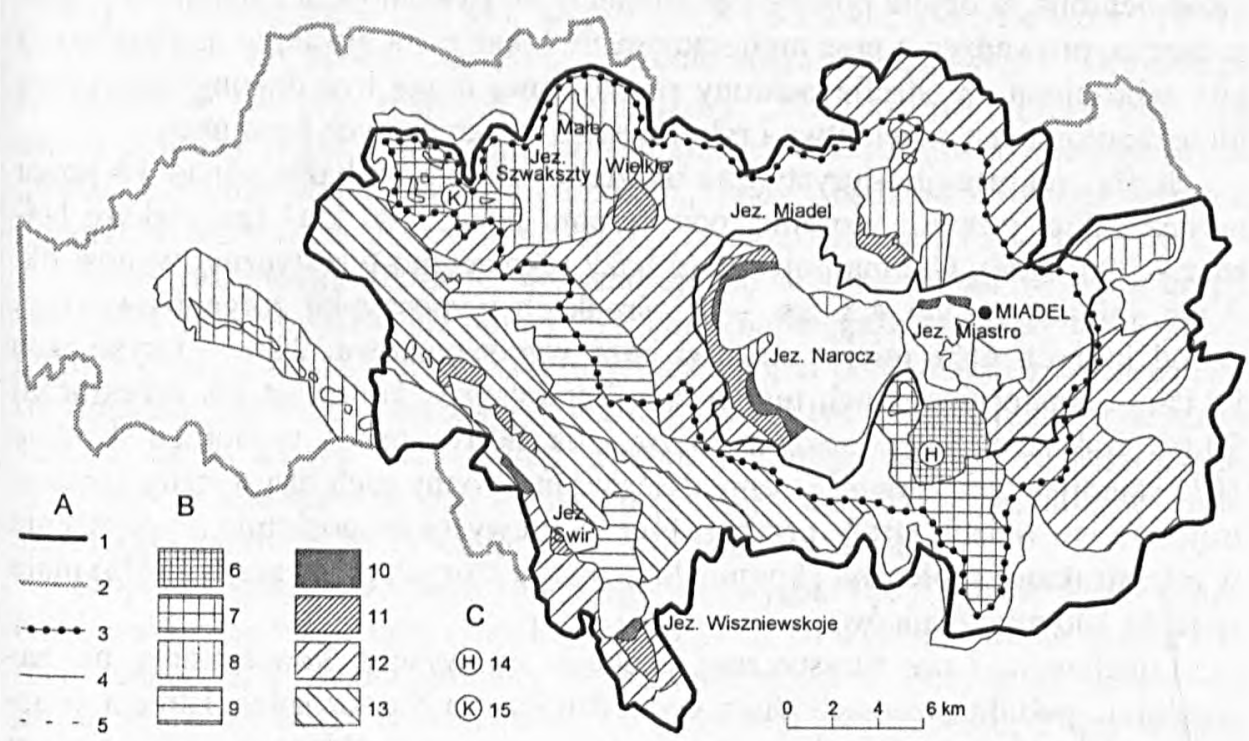

Rys. 2. Struktura zagospodarowania przestrzennego projektowanego Naroczańskiego Parku Narodowego: A - granice parku: 1 - wedlug wariantu optymalnego, 2 - perspektywiczna, 3 - według wariantu minimalnego, 4 - strefy buforowej, 5 - zlewni jezior Naroczańskich; B - strefy użytkowania: 6 - ochrony ścisłej etalonów przyrody, 7 - ochrony regulowanej, 8 - ochrony częściowej, 9 - pomników przyrody, 10 - intensywnego zagospodarowania turystycznego, 11 - regulowanego wykorzystania rekreacyjnego, 12 - krajobrazów naturalnych, 13 - terenów myśliwskich; C - istniejące rezerwaty przyrody: 14 - hydrologiczny "Czeremszyca", 15 - krajobrazowy "Jeziora Błękitne" (ź r ó d l o: opracowania na podstawie materiałów Białoruskiego Instytutu Naukowo-Badawczego i Projektowego Rozwoju Miast)

Dessin 2. La structure de l'aménagement spatial du Parc National de Narocz (projeté): A - limites du parc: 1 - selon la variante optimale, 2 - perspective, 3 - selon la variante minimale, 4 - de la zone de tampon, 5 - du bassin des lacs de Narocz; B - zones d'exploitation: 6 - de la protection Stricte des étalons de la nature, 7 - de la protection réglée, 8 - de la protection partielle (réserves), 9 - des curiosités de la nature, 10 - de l'amenagement touristique intensif, 11 - de l'utilisation touristique réglée, 12 - des paysages naturels, 13 - des terrains de chasse; C - réserves naturelles déjà existances: 14 - hydrologique "Czeremszyca", 15 - chorographique "Jeziora Blękitne" (s o u r c e: élaborations à la base des matériaux de l'Institut Scientifique Biélorusse et de l'Institut de Développement des Villes) 
Strefa ścisłej ochrony obejmuje rezerwat hydrologiczny „Czeremczyca” (6,2 tys. ha), gdzie sa zakazane wszelkie rodzaje działalności gospodarczej, oprócz badań naukowych oraz rezerwat krajobrazowy „Jeziora Błękitne"(1,5 tys. ha), gdzie są niezbędne niektóre prace rehabilitacyjne, ukierunkowane na podniesienie odporności biocenoz i jest możliwe ich zwiedzanie turystyczne po wyznaczonych trasach. Strefa regulowanej ochrony obejmuje obszary rezerwatów częściowych (krajobrazowy „Nanosy” i hydrologiczny „Djagili”, botaniczne: „Rudakowo”, „Jezioro Mjadel”, „Nekosecki”, profil geologiczny „Studenec” i in.), gdzie ochroną są objęte pojedyncze elementy ekosystemów, a działalność gospodarcza, prowadzenie prac melioracyjnych, lokalizacja biwaków turystycznych jest zabroniona. W strefie ochrony regulowanej mogą być dokonywane prace biotechnologiczne, zbieractwo i rybołówstwo w określonych terminach.

Strefa rekreacyjno-turystyczna ukształtowała się na bazie ponad 10 jezior naroczańskiej grupy o wspólnej powierzchni ponad $100 \mathrm{~km}^{2}$ (największe Narocz - 79,6 $\mathrm{km}^{2}$ ). Ogólna pojemność bazy rekreacyjno-turystycznej wynosi ok. 7 tys. miejsc, w tym 4,5 tys. - w ośrodkach wypoczynku zorganizowanego, wśród których $66 \%$ miejsc stanowi baza wypoczynkowa, $23 \%$ - turystyczna i $11 \%$ - sanatoryjna. Ruch turystyczno-kuracyjny w końcu lat 80 . przekraczał 90 tys. osób rocznie (w połowie lat 70. - ok. 60 tys. osób), w którege składzie $60 \%$ stanowił ruch zorganizowany. Niezorganizowany ruch turystyczny koncentruje się we wsiach strefy przybrzeżnej (o niewysokim poziomie wyposażenia w infrastrukturę społeczną i komunalna), wśród których przeważają (65\%) małe wsie do 100 mieszkańców.

Lokalizacja bazy turystycznej cechuje się wysoką koncentracją na zachodnim i południowo-zachodnim wybrzeżu jeziora Narocz, gdzie istnieją zwarte kompleksy świeżych lasów sosnowych o niewysokiej chłonności rekreacyjnej (2-5 osób/ha), co powoduje ich degradację już w pierwszych etapach zagospodarowania turystycznego (strefa ośrodków wypoczynkowo-turystycznych). Ogólny stopień zalesienia terenu parku $w$ granicach minimalnego wariantu stanowi około $50 \%$ (lasy uzdrowiskowe zajmują 21,4 tys. ha), co przy uwzględnieniu średniej chłonności różnych typów biocenoz (2-10 osób/ha) pozwala określić pojemność turystyczną na 6,9 tys. osób. W pasie wybrzeży nad jeziorami grupy naroczańskiej (przy normie ekologicznej $25 \mathrm{~m}$ linii brzegowej na 1 miejsce) może być zlokalizowanych ok. 4,6 tys. miejsc, co odpowiada faktycznej pojemności istniejącej bazy turystycznej. Przewiduje się poszerzenie strefy rekreacyjno-turystycznej na tereny położone nad jeziorami Wielkie Szwakszty, Świr', Wisznewskoje, co zwiększa pojemność do 8-10 tys. miejsc.

Strefa gospodarcza obejmuje tereny rolnicze, gospodarki leśnej, przemysłu i osadnictwa, gdzie ze względów ekologicznych powinny być wprowadzone pewne zmiany (preferowanie rolnictwa ekologicznego, stosowanie technologii zamkniętych, budowa oczyszczalni i in.). W strefie ochronnej jezior Narocz, Mjastro i Batorino zabronione jest składowanie nawozów mineralnych i pesty- 
cydów, wyprowadza się obiekty hodowli bydła, zakazana orka ziemi w odległości mniejszej niż $400 \mathrm{~m}$ od linii brzegowej. W stumetrowym pasie wzdłuż brzegów wysadzono 44 ha lasów, na powierzchni 1,5 tys. ha ziemia orna jest przekształcana w łąki.

Park Narodowy „Jeziora Brasławskie” planuje się utworzyć na obszarze 54,4 tys. ha (minimalny wariant) o podobnej strukturze zagospodarowania przestrzennego. Strefa ścisłej ochrony obejmie 5,8 tys. ha ( $11 \%$ obszaru parku), regulowanej ochrony $-19,1$ tys. ha (35\%), turystyczno-rekreacyjna - 13,7 tys. ha (25\%) i gospodarcza - 15,8 tys. ha (29\%) (A l e s z k a, P a r f e n o v 1993). W strefie ochrony ścisłej znajdą się centralne obszary Bogińskiego i Drujskiego kompleksów leśnych, rezerwat krajobrazowy „Mieżjeziorny” (0,44 tys. ha). Strefa ochrony regulowanej, oprócz istniejących rezerwatów hydrologicznych „Riczi”, „Bołoto Moch”, ornitologicznego „Snudy”, będzie poszerzona wskutek utworzenia rezerwatów geomorfologicznych, botanicznych oraz krajobrazowych.

Strefa rekreacyjno-turystyczna kształtuje się na bazie ponad 30 jezior grupy brasławskiej o powierzchni ponad $110 \mathrm{~km}^{2}$ (największe Driwiaty - $36 \mathrm{~km}^{2}$ ). Ogólny poziom zagospodarowania turystycznego, w porównaniu z Parkiem Naroczańskim, jest niższy. Baza turystyczna liczy 1,5 tys. miejsc, ruch turystyczny szacuje się na 25 tys. osób, wśród których dominuje (ok. 3/4) ruch niezorganizowany w miejscowościach wiejskich (z reguły małych - wsie do 100 mieszkańców stanowią $75 \%$ ich liczby w strefie przybrzeżnej).

Stopień zagospodarowania rolniczego jest wysoki ( $60 \%$ zlewni jezior grupy brasławskiej zajmuja grunty orne, lasy około $25 \%$ ), co wymaga wprowadzenia szeregu ograniczeń i zmiany struktury użytkowania terenów. Przewiduje się rozwiązać te problemy przez utworzenie strefy buforowej (o szerokości $2 \mathrm{~km}$ wzdłuż granic parku), co napotyka na pewne bariery i opór obecnych użytkowników.

Ogólny kompleks powiązań systemowych pomiędzy różnymi podmiotami użytkowania terenów i zagospodarowania przestrzennego obszarów parków narodowych, charakter ewentualnych wydatków (nakładów) i dochodów związanych $\mathrm{z}$ funkcjami turystycznymi, w zgeneralizowanej formie przedstawiono w tab. III. Warto przy tym podkreślić, że większa część dochodów będzie akumulowana poza granicami parków narodowych (krajobrazowych), wywołując jednak efekty multiplikacji w całej gospodarce regionów i kraju.

Ogólnie można stwierdzić, że planowany układ przestrzennego zagospodarowania parków narodowych Białorusi w większym stopniu nawiązuje do parków krajobrazowych (landszaftnych) o znaczeniu regionalnym (których nie uwzględnia obecny system obszarów chronionych Białorusi), niż do parków narodowych o znaczeniu ogólnopaństwowym w definicji Międzynarodowej Rady ds. Ochrony Przyrody (Z a b e 1 in a 1987). Stwarza to pewne przesłanki do kontynuowania prób szerszego wprowadzenia (przy braku w systemie obszarów przyrodniczo-chronionych terenów o pierwszorzędnych funkcjach turystycznych) 
Powiązania wydatków i dochodów z użytkowania turystycznego obszarów parków narodowych

Les rapports entre les dépenses et les revenus résultant de l'exploitation touristique des terrains des Parcs Nationaux

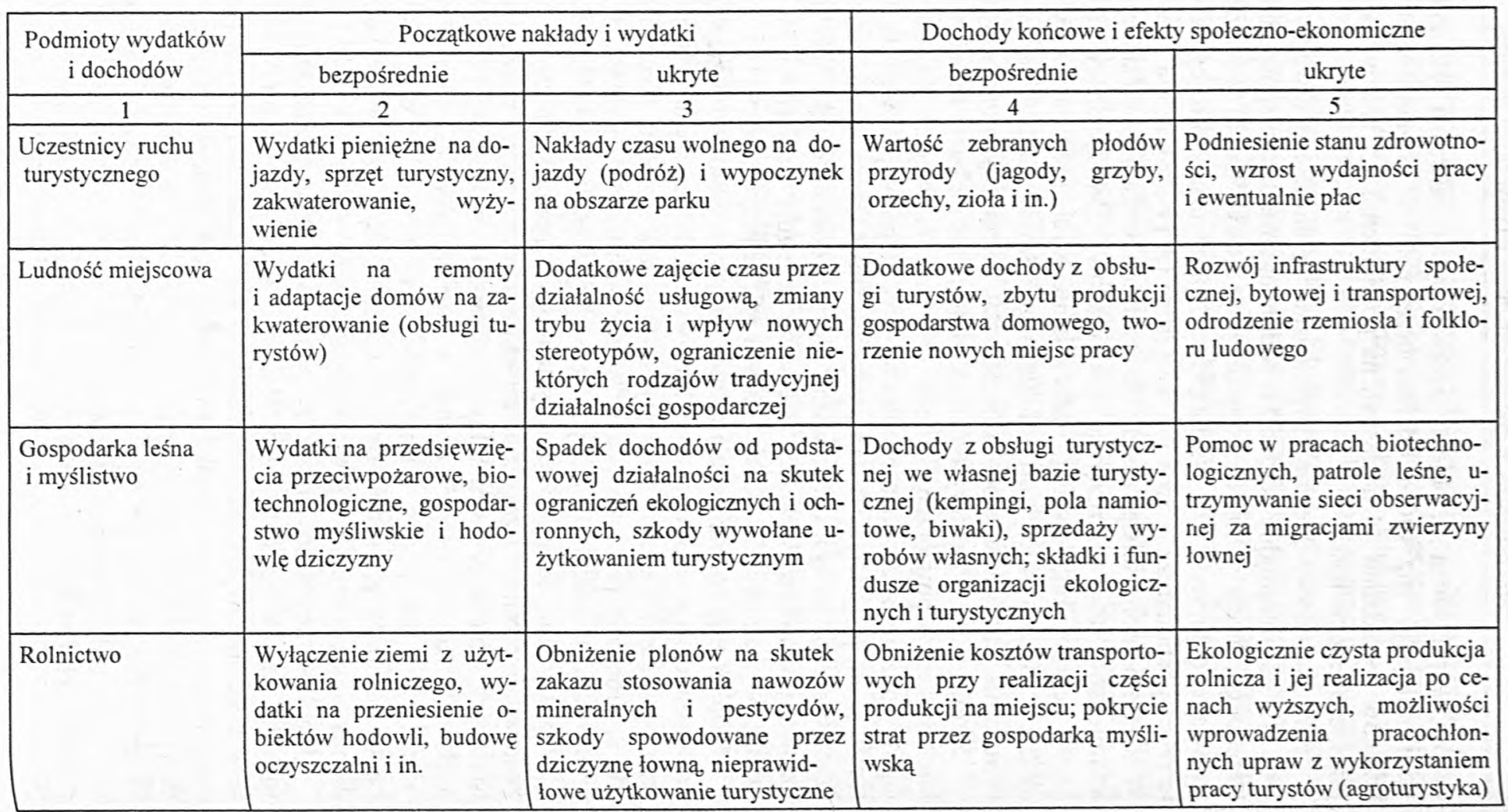

\begin{tabular}{|c|c|c|c|c|}
\hline Obsługa turystyczna & $\begin{array}{l}\text { Nakłady na budowę i u- } \\
\text { trzymanie infrastruktury } \\
\text { turystycznej (baza nocle- } \\
\text { gowa, żywieniowa, obiek- } \\
\text { ty uzupełniające) }\end{array}$ & $\begin{array}{l}\text { Wydatki dodatkowe na infra- } \\
\text { strukturę związaną z ekologi- } \\
\text { cznym i ochronnym statusem } \\
\text { obszarów parku }\end{array}$ & $\begin{array}{l}\text { Dochody z obsługi turystów, } \\
\text { organizacji szkolenia ekologi- } \\
\text { cznego i turystycznego }\end{array}$ & $\begin{array}{l}\text { Renta różniczkowa wskutek } \\
\text { wykorzystania unikatowych } \\
\text { zasobów turystycznych, obni- } \\
\text { żenie sezonowości ruchu tu- } \\
\text { rystycznego }\end{array}$ \\
\hline Ochrona środowiska & $\begin{array}{l}\text { Wydatki na projekt zagos- } \\
\text { podarowania przestrzen- } \\
\text { nego, monitoring ekologi- } \\
\text { czny i badania naukowe, } \\
\text { utrzymanie muzeum przy- } \\
\text { rody, zwierzyńca i ście- } \\
\text { żek ekologicznych }\end{array}$ & $\begin{array}{l}\text { Dodatkowe nakłady na oznako- } \\
\text { wanie ścieżek ekologicznych i } \\
\text { tras turystycznych, szkody wy- } \\
\text { wolane innymi użytkownikami } \\
\text { i turystami, kłusownictwo }\end{array}$ & $\begin{array}{l}\text { Dochody z obsługi wycieczek } \\
\text { i grup turystycznych w mu- } \\
\text { zeum przyrody, na ścieżkach } \\
\text { ekologicznych, realizacji ma- } \\
\text { teriałów informacyjnych (fol- } \\
\text { dery, mapy, widokówki i in.) }\end{array}$ & $\begin{array}{l}\text { Edukacja i wychowanie ekolo- } \\
\text { giczne, rozwój społecznych } \\
\text { form ochrony przyrody i ru- } \\
\text { chów ekologicznych }\end{array}$ \\
\hline
\end{tabular}

Źr ó d lo: opracowanie własne. 
turystycznego użytkowania parków narodowych, rezerwatów i rezerwatów biosfery w warunkach zachwianej równowagi ekologicznej na Białorusi.

\section{UWAGI KOŃCOWE}

W warunkach recesji gospodarczej, wywołanej przejściowym okresem reformowania systemów społeczno-gospodarczych oraz zachwianiem równowagi ekologicznej w wyniku nadmiernego uprzemysłowienia, przekształcenia środowiska przyrodniczego przez meliorację, katostrofy ekologicznej i in., wzrasta znaczenie systemu obszarów chronionych. Jednym z podstawowych jego elementów na Białorusi są rezerwaty (zapowiedniki) państwowe i rezerwaty biosfery, których sieć wymaga rozszerzenia zarówno pod kątem problemów własnego kraju, jak i kształtowania spójnego i ciagłego ekologicznie systemu obszarów chronionych regionu Europy Środkowej i Wschodniej. Wzrost presji antropogenicznej (w fazie przejścia od społeczeństwa przemysłowo-zurbanizowanego do postindustrialnego) na unikatowe obszary chronione wymaga ścisłego określenia ich funkcji i form zagospodarowania przestrzennego. Funkcja turystyczna, jako odrębny typ użytkowania przestrzeni, wymaga odrębnego kształtowania areału ziemi i nie może być sprowadzona tylko do drugorzędnego użytkownika na terenach o innym przeznaczeniu celowym (w tym na obszarach chronionych). Wymaga to w warunkach Białorusi rozszerzenia typów (kategorii) obszarów chronionych o dominujących funkcjach turystycznych (parki krajobrazowe, przyrodniczo-rekreacyjne i in.).

Przeprowadzona analiza planów utworzenia parków narodowych na obszarach atrakcyjnych turystycznie wykazała, że będzie to służyć w pewnej mierze uporządkowaniu ładu przestrzennego na ich terenach i zwiększeniu udziału obszarów ścisłej i regulowanej ochrony. Jednak istniejący stan ich zagospodarowania turystycznego na granicy równowagi ekologicznej, może być zachwiany bądź przez intensyfikację użytkowania turystycznego, bądź pod wpływem innych form gospodarowania, które powinny być poddane pewnej rekonstrukcji przy nadaniu tym obszarom statusu parków narodowych. W praktyce wywołuje to powstanie szeregu konfliktów przestrzennych i społecznych.

Konflikty przestrzenne powstają pomiędzy różnymi użytkownikami obszarów chronionych. Nadmierne zagospodarowanie i ruch turystyczny (razem z innymi funkcjami gospodarczymi) często zagraża obszarom ścisłej ochrony i walorom rekreacyjno-turystycznym. Konflikty społeczne często są skutkiem ignorowania interesów ludności miejscowej, która nie przyjmuje statusu i reżymów ochrony parków narodowych. Zmianom struktury i systemów gospodarowania na ich terenach powinny towarzyszyć przedsięwzięcia dotyczące stworzenia nowych miejsc pracy (z wykorzystaniem miejscowych surowców naturalnych), odrodzenia rzemiosł ludowych i uporządkowania funkcji zbieracko-łowieckich 
(z preferowaniem interesów ludności miejscowej i turystów). W celu uniknięcia takich konfliktów niezbędne są działania zarówno na szczeblu centralnym (baza ustawowo-normatywna, finansowanie programów o znaczeniu ogólnokrajowym), jak i regionalnym, zawierającym opracowanie kompleksowych programów ekologicznego, turystycznego i społeczno-gospodarczego rozwoju obszarów chronionych i parków narodowych.

\section{PIŚMIENNICTWO}

A l e s z k a V., P a r f e n o v V., 1993, Kto sochranit żemczużinu: Byt' ili nie byt' nacionalnomu parku Braslavskie ozera, Sovetskaja Belorussija, 15 VII 1993, s. 3.

D z j a 1 l a v A., 1994, Zapavednik z "baradoj" abo pakutlivaja chadzba pa bagne, Rodnaja pryroda, nr 3, s. 14-15.

L u c z k o v A. I., 1993, Pryroda Belarusi: Suczasnasc'i buduczynja, Navuka i technika, s. 55-58.

M u r a u j e v Z., 1994, Zapavednasc': plany i realnasc', Rodnaja pryroda, nr 6, s. 12-13.

P i r o ż n i k I., 1976, Turyzm i vykarystanne zjamli, Rodnaja pryroda, nr 2, s. 26.

P i r o ż n i k I., 1992, Spoleczno-geograficzne tendencje rozwoju i przestrzennej organizacji zagospodarowania turystycznego (na przykladzie ZSRR w latach 1976-1990), UŚ, Sosnowiec.

P i r o ż n i k I., 1993, Geograficzne uwarunkowania rozwoju zagranicznej turystyki przyjazdowej do Biatorusi. Uwarunkowania rozwoju turystyki zagranicznej w Europie Środkowej $i$ Wschodniej (Materiały międzynarodowego seminarium), z. 2, Wyd. Uniwersytetu Wrocławskiego, Wrocław, s. 71-89.

P ot a e v G. A., J u r ge n s o n N. A., B u g a e n k o V. M., 1993, Problemy $i$ perspektivy razvitija Naroczanskogo regiona. Ekologiczeskoe i socialno-ekonomiczeskoe obosnovanie regionalnych schem racionalnogo prirodopolzovanija (Tez. dokl. Respubl. naucz. konf.), Minsk, s. 75-76.

Z a b e 1 i n a N. M., 1987, Nacionalnyj park, Mysl, s. 160-161.

Doc. dr hab. Iwan I. Pirożnik

Uniwersytet Bialoruski, Wydzial Geograficzny

Katedra Geografii Ekonomicznej Państw Zagranicznych

prospekt F. Skaryny 4

220050 Mińsk

Bialoruś
Wpłynęlo:

21 października $1995 \mathrm{r}$.

\section{RÉSUMÉ}

Dans les conditions de la pression faite par l'homme sur la nature, croît toujours la valeur des paysages uniques. La terrains de la nature protégée (parcs nationaux, parcs de paysage, réserves) jouisent d'un grand intérêt. L'élargissement des formes de leur expolitation touristique s'oppose souvent aux fonctions écologiques et protectrices et mène aux conflits spatiaux et sociaux.

Le système des terrains protégés est représenté en Biélorussie par les réserves d'état, les parcs nationaux, les réserves partielles et les couriosités de la nature. Les terrains complexes de pro- 
tection de la nature (réserves, parc national) occupent $1,1 \%$ de la superficie du pays (tabl. I) et les autres terrains protégés de tours les types - 3,7\%. Les perturbations de l'équilibre écologique en Biélorussie causées par l'amélioration et l'utilisation excessive des produits chimiques en agriculture, par les pollutions industrielles et radioactives après la détérioration de l'usine thérmique de Tchernobyl (plus de $46500 \mathrm{~km}^{2}=23 \%$ du territoire du pays ont été souillés) exigent que les travaux ayant pour but la formation complexe des terrains protégés soient intensifiés. Un tel système outre l'augmentation du nombre des réserves (de Nalibocz, de Swisłocz et Berezyna, de Suraż) doit prendre en considération les intérêts du tourisme, en tant que type à part de l'utilisation de la terre. L'analyse du degré de l'exploitation touristique complémentaire, y compris les fonctions écologiques des terrains protégés (tabl. II), a démontré que dans les réserves de biosphère, seules quelques fores du tourisme instructif et éducatif sont possibles à pratiquer. Le Parc National "La Forêt de Białowieża" embrassant le terrain forestier exceptionnel n'était auparavant qu'une réserve de chasse et ne dispose pas de dépendances touristiques; la structure de son aménagement exige quelques innovations.

Les terrains protégés doivent être complétés par les parcs nationaux projetés, parmi lasquels les plus attrayants pour les touristes pourraient être ceux de Narocz et de Bracław. Dans la structure de leur aménagement spatial, on prend en considération avant tout la fonction touristique, en tant que'une des formes essentielles d'exploitation. Ayant égard aux intérêts de tous les usagers et aux fonctions écologiques, on prévoit quelques zones: de stricte protection (13\% dans le Parc de Narocz), de protection réglée (15\% environ), d'aménagement touristique (32\%) et économique $(40 \%)$. Le niveau actuel de l'aménagement touristique dans la région de Narocz est à l'état d'équilibre écologique (environ 4500 lieux de couchage, 90000 visiteurs par an), cependant quelques entreprises pour élevar la force de résistance et d'absorptivité du complexe hydrologique et chorographique sont indispensables. L'aménagement touristique de la région des lacs de Bracław est plus modeste (1500 lieux de couchage, 25000 touristes par an). C'est l'aménagement agricole qui y est au haut degré. Il est l'amenagement agricole qui y est au haut degré. Il est difficile d'harmoniser les intérêts économiques avec les fonctions écologiques et touristiques. Le tableau III présente le complexe de liaisons entre les sujets différents exploitant les terrains des parcs nationaux. Il est à soulinger que le tourisme donne quelques effets de multiplication dans l'économie des régions en laissant la plupart des revenus à l'extérieur des parcs nationaux. Pour éviter les conflits spatiaux et sociaux sur le terrain des parcs nationaux, il faut élaborer les programmes complexes de leur développement écologique, touristique et socio-économique.

Traduit par Lucjan Kowalski

\section{SUMMARY}

Under the condition of growing anthropopressure on the natural environment, the value of unique landscape areas is also increasing. Areas of protected nature (national and landscape parks, reservations) are very popular among tourists. Developing the forms of the tourist use of these areas is often inconsistent with their ecological-protective functions and causes spatial and social conflits.

The system of protected areas in Bielorussia is represented by state reservations, national parks (partial reservations) and monuments of nature. The areas of complex nature protection (reservations, national parks) constitute $1,1 \%$ of the country's area (Table I). The protected areas of all types cover $3,7 \%$ of the country's area. The disturbance of the ecological balance in Bielorussia caused by irrigation and the use of chamicals in agriculture, industrial pollution and radioactive contamination after the Chernobyl disaster (46 $500 \mathrm{~km}^{2}-23 \%$ of the country's area) calls for intensified efforts so as to create a complex system of protected areas. Apart from the expected 
increase in the number of reservations (Nabolicki, Swislocki-Berezynski, Surazski), such system should consider the interests of tourism as a separate type of using the area. An analysis of the complementarity of the tourist use and the ecological functions of the protected areas (Table II) shows that it is possible to practise only selected forms of cognitive tourism in the reservations of the biosphere. Bialowieska Forest, a national park created on a unique forest area, originated from a reservation and does not offer appropriate tourist facilities. The structure of its spatial arrangement needs certain changes.

The basic formation complementing the protected areas should be national parks. Touristically most attractive are the Naroczanski and Braslawski National Parks. In the structure of their spatial arrangement, tourist functions are considered one of the basic forms of use. In order to meet the interests of different users and the requirements of ecological functions, a strict protection zone (13\% in the Naroczanski National Park) and an economic zone (40\%) have been established. The tourist facilities in the Narocznski region are ecologically balanced (about 4500 tourist places; annual traffic of 90000 people), which requires several actions after the resistance and absorptiveness of the hydrological landscape complex have risen. The region of the Bratyslavskie lakes is less rich in tourist facilities ( 1500 tourist places: traffic -25000 people) but is highly developed agriculturally, which makes it difficult to reconcile the economic interests with the ecological and tourist functions. The network of system connections among variaous users of national parks is presented in Table III. It is worth noticing that tourism causes some effects of multiplication in the economy of the regions, leaving most of the income outside the national parks, it is essential to devise complex programs as to their ecological tourist and social-economic development. 